\title{
Performance of Durum Wheat (Triticum durum) Genotypes under Variable Sowing Dates in Sub-Tropical Zone of Jammu, Jammu \& Kashmir
}

\author{
Sanjay Swami ${ }^{1}$, B.R. Bazaya ${ }^{2} *$ and G.N. Gurjar ${ }^{1}$ \\ ${ }^{1}$ School of Natural Resource Management, College of Post Graduate Studies, \\ Umiam, India \\ ${ }^{2}$ Sher-e-Kashmir University of Agricultural Sciences and Technology-Jammu, India \\ *Corresponding author
}

\section{A B S T R A C T}

Keywords

Durum wheat, genotypes, sowing dates, yield and Sub-tropical zone of Jammu

Article Info

\section{Accepted:}

07 February 2019

Available Online:

10 March 2019
A field experiment was conducted at research farm of Sher-e-Kashmir University of Agricultural Sciences and Technology of Jammu on sandy loam soil of Sub-tropical zone of Jammu division to investigate the effect of sowing dates and genotypes on growth, yield and nitrogen uptake of durum wheat (Triticum durum) for two consecutive rabi seasons. The treatments comprised of two sowing dates viz. $\mathrm{D}_{1}$-normal sown and $\mathrm{D}_{2}$-late sown in the main plot, and four genotypes viz. PBW-34, PDW-233, WH-896 and PBW-343 in the sub plots were evaluated under split plot design with three replications. Results revealed that variety PBW-343 recorded significant higher number of ear heads, grain and biological yield per $\mathrm{m}^{2}$ area than that of all other genotypes. Among sowing dates, normal sown wheat crop recorded significant higher grain and biomass yield as compared to late sown wheat. In normal sown wheat $\left(\mathrm{D}_{1}\right), \mathrm{N}$ uptake in grain was also recorded significantly higher in both the consecutive years whereas, among different genotypes, PBW-343 recorded highest $\mathrm{N}$ uptake in grain and straw in second year of cropping.

\section{Introduction}

Wheat is the most important cereal crop because it is the staple food of the people of India and thus occupies a central position in forming agricultural policies and dominates all crops in acreage and production. The spectacular increase in the area, production and yield of wheat from merely 12.57 million hectares, 10.40 million tonnes and $837 \mathrm{~kg} \mathrm{ha}^{-1}$ during 1965-66 to 30.42 million hectares, 92.29 million tonnes and $3034 \mathrm{~kg} \mathrm{ha}^{-1}$ during
2015-16 (Directorate of Economics and Statistics, 2018) has not only elevated over status from "shortage" to "surplus" in wheat but also opened new avenues for its diversified utilization. Despite of impressive achievements in recent past, concentrated efforts are still needed for achieving sustained growth in wheat production to fulfill nutrient requirements for ever increasing population and for maintaining buffer stock for food security (Tripathi and Mishra, 2017). It has been projected that India will have to produce 
at least 109 million tonnes of wheat by 2020 AD to feed 1.3 billion population and for meeting the demand under diversified uses, which seems to achieve only through elevating productivity up to $4000 \mathrm{~kg} \mathrm{ha}^{-1}$ (Nagarajan, 1988). Renewed research and development efforts are needed to exploit potential of major wheat growing areas not only in quantitative terms but also in qualitative terms. The development and identification of high yielding, widely adopted, disease resistance varieties with good quality characteristics is considered the first and foremost to generate production technology for a region to increase productivity of wheat. As wheat is sown in winter, it has its own definite requirements for temperature and light for emergence, growth and flowering (Dabre et al., 1993). Late sowing results in poor tillering and crop grow generally slow because of low temperature. In late planting the wheat genotype should be of short duration that may escape from high temperature at the grain filling stage (Phadnawis and Saini, 1992). Ansary et al., (1989) reported that delay sowing suppressed the yield, caused by reduction in the yield contributing traits like number of tillers, number of grains per spike and grain yield. Rajput and Verma (1994) observed that normal sowing gave higher grain yield than late sowing. Early sowing always produces higher yield than late sowing. Each day delay in sowing from $20^{\text {th }}$ November decreases grain yield @ $39 \mathrm{~kg} \mathrm{ha}^{-1}$ per day (Singh and Uttam, 1999). According to Shafiq (2004) and Anwar et al., (2015), early sowing of wheat enhances germination per unit area, plant height, spikelets per spike, number of grain per spike and 1000-grain weight over late sowing. Many high yielding genotypes have been evolved and recommended for general cultivation in the past. These genotypes are loosing their yield potential due to changes in various edaphic and environmental conditions. Choice of a suitable genotype for different sowing time further gets prime importance for wheat, being a thermo-sensitive crop. However, there is paucity of information on this aspect in the region. Therefore, keeping this in view, the present investigation was carried out to study the performance of durum wheat (Triticum durum) genotypes under different sowing times in Sub-Tropical Zone of Jammu, Jammu \& Kashmir.

\section{Materials and Methods}

Field experiments were conducted at Research Farm of Sher-e-Kashmir University of Agricultural Sciences and Technology of Jammu to investigate the effect of sowing dates and genotypes on growth, yield and nitrogen uptake of durum wheat (Triticum durum) for two consecutive rabi seasons. The soil of experimental site was sandy loam with $\mathrm{pH} 7.3$, low in organic carbon $(0.36 \%)$ and available $\mathrm{N}$ (190 $\left.\mathrm{kg} \mathrm{ha}^{-1}\right)$, and medium in available $\mathrm{P}\left(150 \mathrm{~kg} \mathrm{ha}^{-1}\right)$ and available $\mathrm{K}$ (162 $\left.\mathrm{kg} \mathrm{ha}^{-1}\right)$. The experiment was replicated thrice in split plot design with two sowing times viz. normal $\left(14^{\text {th }}\right.$ November) and late $\left(28^{\text {th }}\right.$ November) as main plot treatments and four genotypes viz. PBW-34, PDW-233, WH-896 and PBW-343 as sub plot treatments. The crop was sown $20 \mathrm{~cm}$ apart with a seed rate of 100 $\mathrm{kg} \mathrm{ha}^{-1}$. The crop received a uniform dose of

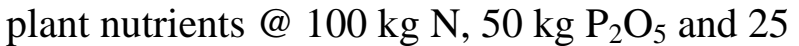
$\mathrm{kg} \mathrm{K}_{2} \mathrm{O}$ ha $^{-1}$ through urea, di-ammonium phosphate and muriate of potash, respectively. Half of nitrogen and full dose of phosphorus and potash were applied as basal at the time of sowing. Remaining nitrogen was applied after first irrigation at crown-root initiation stage. Irrigations were applied to crop based on crop demands during both the years.

\section{Results and Discussion}

\section{Performance of durum wheat under variable sowing time}

Time of sowing significantly influenced the growth characters and yield attributes of wheat 
(Table 1). Plant height of normal sown wheat was 4.27 and 9.2 per cent higher in the consecutive rabi seasons, respectively. Decrease in plant height in late sowing was due to shorter growing period. Early sown crop may have enjoyed the better environmental conditions especially the temperature and solar radiation which resulted to tallest plants. These results are in line with those reported by Shahzad et al., (2002) and Anwar et al., (2015). Further, it was observed that normal sown crop produced significantly higher number of spikes per square meter and 1000 grain weight in both the consecutive rabi seasons. The parameters decreased with delay in sowing. Normal sown crop produced 2.7 and 7.0 per cent more spikes per $\mathrm{m}^{2}$ than late sown crop during the first and second year, respectively. Less number of grains per spike in late sowing was due to less production of photosynthates due to shorter growing period. These results are in line with those of Shahzad et al., (2002). Moreover, the early sowing resulted in better development of the grains due to longer growing period. These findings are strongly supported by those of Spink et al., (2000) and Anwar et al., (2015) who had also reported decreased 1000-grain weight with delay in sowing.

Grain and straw yields of wheat were significantly affected due to sowing time (Table 2). Delayed sowing reduced the grain yield by 10.4 and 8.9 per cent in the first and second year of experimentation, respectively. Thus, late sowing of wheat caused yield reduction of $25 \mathrm{~kg} \mathrm{ha}^{-1}$ day $^{-1}$ as compared to normal sowing in both the years. Straw yield of late sown wheat was also significantly lower as compared to its normal sowing. The higher grain and straw yield in normal sown wheat crop may be attributed to better plant growth leading to significantly taller plants and more number of spikes per $\mathrm{m}^{2}$ and better partitioning of photosynthesis in comparison to delayed sowing. The improvement in yields attributes may be owing to more time available for better use of growth resources and expression of its potential. These findings corroborate that of Shiwani et al., (2003), Gupta et al., (2007) and Anwar et al., (2015). Dry matter accumulation was also significantly higher in normal sown crop than late sown crop (Table 2).

Table.1 Effect of sowing dates and genotypes on growth and yield attributes of durum wheat (Triticum durum)

\begin{tabular}{|c|c|c|c|c|c|c|c|c|}
\hline \multirow[t]{2}{*}{ Treatments } & \multicolumn{2}{|c|}{ Plant height (cm) } & \multicolumn{2}{|c|}{ No. of spike/m² } & \multicolumn{2}{|c|}{ Grains per spike } & \multicolumn{2}{|c|}{ Test weight } \\
\hline & $\mathbf{Y}_{1}$ & $\mathbf{Y}_{2}$ & $Y_{1}$ & $\mathbf{Y}_{2}$ & $\mathbf{Y}_{1}$ & $\mathbf{Y}_{2}$ & $Y_{1}$ & $\mathbf{Y}_{2}$ \\
\hline \multicolumn{9}{|c|}{ Date of sowing } \\
\hline $\mathbf{D}_{1}$ & 87.00 & 104.58 & 362.25 & 371.83 & 53.91 & 50.91 & 41.79 & 43.46 \\
\hline $\mathbf{D}_{2}$ & 83.50 & 95.75 & 352.50 & 345.66 & 51.75 & 45.58 & 40.28 & 40.65 \\
\hline$C D(p=0.05)$ & 3.05 & 6.03 & 9.70 & 24.61 & NS & NS & 1.35 & 1.79 \\
\hline \multicolumn{9}{|l|}{ Genotypes } \\
\hline$V_{1}$ PBW-34 & 85.33 & 100.50 & 356.66 & 364.00 & 52.16 & 50.16 & 41.12 & 43.26 \\
\hline$V_{2}$ PDW-233 & 85.16 & 97.83 & 352.56 & 341.66 & 50.00 & 43.66 & 40.42 & 40.01 \\
\hline V 3 WH- 896 & 99.83 & 53.16 & 355.00 & 348.33 & 53.16 & 47.83 & 40.90 & 41.18 \\
\hline$V_{4}$ PBW-343 & 102.50 & 56.00 & 365.33 & 382.50 & 56.00 & 51.33 & 41.71 & 43.78 \\
\hline$C D(p=0.05)$ & NS & NS & 10.11 & 23.83 & NS & NS & NS & NS \\
\hline
\end{tabular}


Table.2 Effect of sowing dates and genotypes on yield $\left(\mathrm{q} \mathrm{ha}^{-1}\right)$ of durum wheat (Triticum durum)

\begin{tabular}{|c|c|c|c|c|}
\hline \multirow[t]{2}{*}{ Treatments } & \multicolumn{2}{|c|}{ Grain yield $\left(q\right.$ ha $\left.^{-1}\right)$} & \multicolumn{2}{|c|}{ Dry matter yield $\left(\mathrm{q} \mathrm{ha}^{-1}\right)$} \\
\hline & $\mathbf{Y}_{1}$ & $\mathbf{Y}_{2}$ & $\mathbf{Y}_{1}$ & $\mathbf{Y}_{2}$ \\
\hline \multicolumn{5}{|c|}{ Date of sowing } \\
\hline$D_{1}$ & 33.64 & 39.80 & 116.16 & 107.66 \\
\hline $\mathbf{D}_{2}$ & 30.12 & 36.26 & 105.83 & 96.50 \\
\hline $\mathrm{CD}(\mathrm{p}=0.05)$ & 2.22 & 2.51 & 9.41 & 10.08 \\
\hline \multicolumn{5}{|l|}{ Genotypes } \\
\hline$V_{1}$ PBW-34 & 32.60 & 39.41 & 110.83 & 106.50 \\
\hline$V_{2} P D W-233$ & 30.25 & 31.60 & 106.33 & 93.16 \\
\hline$V_{3}$ WH- 896 & 31.35 & 34.73 & 106.66 & 99.16 \\
\hline$V_{4} P B W-343$ & 33.33 & 46.40 & 120.16 & 109.50 \\
\hline $\mathrm{CD}(\mathrm{p}=0.05)$ & 1.04 & 3.70 & 9.82 & 9.27 \\
\hline
\end{tabular}

Table.3 Effect of sowing dates and genotypes on nitrogen uptake $\left(\mathrm{kg} \mathrm{ha}^{-1}\right)$ by durum wheat (Triticum durum)

\begin{tabular}{|c|c|c|c|c|}
\hline \multirow[t]{2}{*}{ Treatments } & \multicolumn{2}{|c|}{ Grain } & \multicolumn{2}{|c|}{ Straw } \\
\hline & $\mathbf{Y}_{1}$ & $\mathbf{Y}_{2}$ & $Y_{1}$ & $\mathbf{Y}_{2}$ \\
\hline \multicolumn{5}{|c|}{ Date of sowing } \\
\hline$D_{1}$ & 52.2 & 60.57 & 46.73 & 45.50 \\
\hline $\mathbf{D}_{2}$ & 43.60 & 54.94 & 44.62 & 40.94 \\
\hline $\mathrm{CD}(\mathrm{p}=0.05)$ & 4.18 & 3.01 & NS & NS \\
\hline \multicolumn{5}{|l|}{ Genotypes } \\
\hline$V_{1}$ PBW-34 & 50.10 & 59.81 & 44.18 & 44.92 \\
\hline$V_{2} P D W-233$ & 46.88 & 52.57 & 43.60 & 38.58 \\
\hline$V_{3}$ WH- 896 & 46.52 & 47.20 & 46.50 & 41.43 \\
\hline$V_{4} P B W-343$ & 48.10 & 71.46 & 48.48 & 47.45 \\
\hline $\mathrm{CD}(\mathrm{p}=0.05)$ & NS & 5.93 & NS & 4.95 \\
\hline
\end{tabular}

The reduction in dry matter production with delay in sowing time may be due to reduction in duration of tillering phase with delayed sowing resulting in lesser dry matter production in both the years. This is in accordance to the finding of Sardana et al., (2002), Shiwani et al., (2003) and Anwar et al., (2015). Nitrogen uptake in grain of wheat was recorded significantly higher in normal shown crop (Table 3) in both the years, whereas $\mathrm{N}$ uptake in straw was found to be non-significant. Similar results were also obtained by Iqbal et al., (2012).

\section{Performance of durum wheat genotypes}

Perusal of data presented in Table 1 revealed that genotypes of wheat did not differ in plant 
height and other growth characters like number of grains per spike and 1000 grain weight. However, the genotype PBW-343 produced significantly higher grain yield (33.33 and $46.40 \mathrm{~kg} \mathrm{ha}^{-1}$ during the first and second year of experimentation, respectively) and straw yield than all other genotypes but remained at par with PBW-34 genotype. Since wheat yield formation is a complex process and governed by complimentary interaction between source (photosynthesis and availability of assimilates) and sink component (storage organs). Thus, as a consequence of marked important in both these regulative process as evinced from higher accumulation of biomass and number of spikes per $\mathrm{m}^{2}$ under variety PBW-343 led to significant increase in production of grain and straw yields. Genotypes PDW-233 recorded lowest grain yield (30.25 and 31.60 $\mathrm{q} \mathrm{ha}^{-1}$ ) in the consecutive rabi seasons, respectively.

Similar results were reported by Kulkarni et al., (2003) and Gupta et al., (2007). The data presented in Table 3 on nitrogen uptake revealed that $\mathrm{N}$ uptake was non-significant in wheat grain and straw under various genotypes in first year whereas it was found to be significantly higher in PBW-343 in comparison to other genotypes in second year. These results are in close conformity with the results obtained by Iqbal et al., (2012)

In conclusion, on the basis of experimental findings, the farmers of Sub-Tropical Zone of Jammu, Jammu \& Kashmir may be advised to raise PBW-343 durum wheat (Triticum durum) genotypes under normal sowing date i.e. $14^{\text {th }}$ November for getting optimum production.

\section{References}

Ansary, A.H., Khushak, A.M., Sethar, M.A., Ariam, N.A. and Emon, M.Y.M.
(1989). Effect of sowing dates on growth and yield of wheat cultivars. Pak. J. Sci. Ind. Res., 32: 39-42.

Anwar, S., Khattak, W.A., Inamullah, Islam, M., Bashir, S., Shafi, M. and Bakht, J. (2015). Effect of sowing dates and seed rates on the agro-physiological traits of wheat. J. Environ. Earth Sci., 5 (1): 135-141.

Dabre, W.M., Lal, S.B. and Lngole, G.L. (1993). Effects of sowing dates on yield, ear number, stomatal frequency and stomatal index in wheat. $J$. Maharashatra Agri. Univ., 18: 64-66.

Directorate of Economics and Statistics (2018). Agricultural Statistics at a Glance 2017. Department of Agriculture, Cooperation \& Farmers Welfare, Ministry of Agriculture \& Farmers Welfare, Government of India, New Delhi.

Gupta, A. K.; Gupta, M. and Singh, P. (2007). Production potential of wheat (Triticum aestivum) cultivars under late and very late sown conditions in Jammu. Environment and Ecology 2\&3 (4): 1198-1200.

Iqbal, J., K. Hayat, S. Hussain, A. Ali, M.A. Alias and H.A. Bakhsh. (2012). Effect of seeding rates and nitrogen levels on yield and yield components of wheat. Pak. J. Nutr. 11(7): 531-536.

Kulkarni, S.C., Sharma, S.L. and Kantua, S.P. (2003). Effect of varieties, sowing dates and nitrogen levels on yield, nutrient uptake and quality of durum wheat (Triticum durum Deof.) Annals of Agriculture Res. News Series, 24 (2): 332-336.

Nagarajan, S. (1998). Perspective of wheat demand and research needs. In: Wheat research needs beyond 2000 A.D. Nagarajan, S., Singh, G. and Tyagi, B.S. (Eds.), Narosa Publications, pp. 13-27.

Phadnawis, B.N. and Saini, A.D. (1992). Yield models in wheat based on sowing 
time and phenological developments. Ann. Pl. Physio., 6: 52-59.

Rajput, R.L. and Verma, O.P. (1994). Effect of sowing dates on the yield of different varieties of wheat in Chambal Command Area of Madhya Pradesh, Ind. J. Agron., 9: 165-169.

Sardana, V., Sharma, S.K. and Randhawa, A.S. (2002). Performance of wheat (Triticum aestivum) varieties under different sowing dates and nitrogen levels in the sub-mountain region of Punjab. JJA, 47: 372-377.

Shafiq, H.M. (2004). Modeling growth, radiation use efficiency and yield of wheat at different sowing dates and nitrogen levels under arid conditions of Bhawalpur. M.Sc. (Hons.) Thesis, University of Agriculture, Faisalabad, Pakistan.

Shahzad, K., Bakht, J., Shah, W.A., Shafi, M. and Jabeen, N. (2002). Yield and yield components of various wheat cultivars as affected by different sowing dates.
Asian J. Pl. Sci., 1(5): 522-525.

Shiwani, Verma, U.N., Kumar, S., Pal, S.K. and Thakur, R. (2003). Growth analysis of wheat (Triticum aestivum) cultivation under different seeding dates and irrigation levels in Jharkhand. JJA, 48 (4): 282-286.

Singh, V.P.N. and Uttam, S.K. (1999). Influence of sowing dates on yield of wheat cultivars under saline sodic conditions in Central Utter Pradesh. Ind. Agric., 38(1): 64-68.

Spink, J.H., Semere, T., Sparkes, D.L., Whaley, J.M., Foulkers, M.J., Clare, R.W. and Scott, R.K. (2000). Effect of sowing date on plant density of winter wheat. Ann. App. Biol., 137: 179-188.

Tripathi, A. and Mishra, A. (2017). The wheat sector in India: Production, Policies and Food Security. In: The Eurasian Wheat Belt and Food Security: Global and Regional Aspects, Sergio et al., (Eds.), 10.1007/978-3-319-33239-0_17.

\section{How to cite this article:}

Sanjay Swami, B.R. Bazaya and Gurjar, G.N. 2019. Performance of Durum Wheat (Triticum durum) Genotypes under Variable Sowing Dates in Sub-Tropical Zone of Jammu, Jammu \& Kashmir. Int.J.Curr.Microbiol.App.Sci. 8(03): 760-765.

doi: https://doi.org/10.20546/ijcmas.2019.803.093 